\title{
Contractile endothelin-B (ETB) receptors
}

\author{
M. Adner*, L.O. Cardell**, T. Sjöberg ${ }^{+}$, A. Ottosson ${ }^{++}$, L. Edvinsson*
}

Contractile endothelin-B (ETB) receptors in human small bronchi. M. Adner, L.O. Cardell, T. Sjöberg, A. Ottosson, L. Edvinsson. ( ERS Journals Ltd 1996.

ABSTRACT: Endothelins (ETs) are a family of novel regulatory peptides and various lines of evidence suggest an important role for ETs in regulating pulmonary function. Two receptors for endothelin, ETA and ETB, have been found in the human lung, and according to recent studies a non-ETA receptor seems to mediate the contraction of large sized human bronchi. Several studies have emphasized the importance of small bronchi in the pathogenesis of airway disease.

In the present paper, improved methodology was used which enables in vitro studies of small human bronchi down to a diameter of $0.5-1.0 \mathrm{~mm}$. Using the new methodology we have tried to further characterize this receptor.

Small bronchi from the distal parts of the bronchial tree were obtained from pulmonary tissue removed from 15 patients with lung cancer. They were dissected and cut into ring segments, in which isometric tension was recorded.

ET-1, ET-2 and ET-3 elicited strong concentration-dependent contractions of the human small bronchus. Basically, the three peptides were equipotent with about the same maximal response. Upon reapplication, they all showed the same tachyphylaxis pattern, reaching half the initial contraction. Comparative analysis of IRL 1620, a selective ETB receptor agonist, revealed that the effect of the ETB agonist was, in all respects, similar to the responses induced by the ETs. PD 145065, a combined ETA/ETB receptor antagonist competitively inhibited the contractions induced by IRL 1620, whereas FR139317, a selective ETA receptor antagonist, was without effect.

In conclusion, the present study shows that accurate measurements can be made in vitro on small human bronchi and all present data are in favour of an ETB receptor mediating endothelin-induced contraction of human bronchi smaller than $1.0 \mathrm{~mm}$.

Eur Respir J., 1996, 9, 351-355.
Depts of *Internal Medicine, Lund University Hospital, ${ }^{+}$Cardiothoracic Surgery, and ${ }^{++}$Forensic Medicine, Lund University Hospital, Lund, Sweden. **Dept of Otorhinolaryngology, Malmö General Hospital, Malmo, Sweden.

Correspondence: M. Adner

Dept of Cellbiology 1

EB-blocket

Lund University Hospital

S-22185 Lund

Sweden

Keywords: Endothelin-B receptor

endothelins

FR139317

Human small bronchus

IRL 1620

PD 145065

Received: December 21994

Accepted after revision October 201995

Supported by the Swedish Medical Research Council (grant No. 05958 and K95-17P), the Medical Faculty, Lund University, Sweden, the Astra Draco Research Foundation, the Pharmacia Allergy Foundation, the Swedish Society of Medical Research, the Swedish Society of Otorhinolaryngology, the Swedish Association of Allergy and the Swedish Heart and Lung Foundation.
Most studies of isolated human and animal airways refer to experiments performed on trachea or on other relatively large airways. However, several recent reports emphasize the importance of small airways in the regulation and control of different lung functions $[1,2]$. Some studies also indicate that substances like the endothelins (ETs), which can be endogenously released in lung, have different effects in peripheral and central parts of the lung $[3,4]$.

The human ET family consists of ET-1, ET-2 and ET3 , all derived from separate genes [5,6]. Although the ETs are very potent vasoconstrictors, they have effects beyond their vasoconstrictor potential [7]. Aerosol administration of ET-1 induces bronchoconstriction without changes in the pulmonary perfusion pressure, lung wet weight or mediator release, whereas intra-arterial administration of ET-1 results in bronchoconstriction associated with increased pulmonary perfusion pressure, oedema formation and release of eicosanoids [8,9]. Furthermore, cultured airway epithelial cells have the ability to secret both ET-1 and ET-3 [10, 11]. This could indicate a role for the ETs in the airway system.

Two different ET receptors have been cloned; the ETA receptor, with binding affinity for ET-1 = ET-2 >ET-3, and the ETB receptor, with equipotent affinity for the three ET isopeptides $[12,13]$. The ETA receptor is mainly situated on vascular smooth muscle cells mediating constriction, while the ETB receptor is more widely distributed [14]. Both receptor subtypes reside in the human lung [15]. Recent results suggest the involvement of a "non-ETA" receptor in the endothelin-induced contraction of isolated human major bronchi [16]. The exact nature of this receptor has not been characterized and it is not known if the same type of receptor is responsible for the endothelin-induced contraction seen in more distal parts of the bronchial tree.

We have previously demonstrated the presence of ETA and ETB receptors in the guinea-pig lung $[17,18]$. The aim of the present study was to characterize the ET subreceptors in human small airways by the use of different 
pharmacological tools; IRL 1620, a selective ETB receptor agonist [19], FR139317, a selective ETA receptor antagonist $[18,20]$, and PD 145065, a newly developed combined ETA and ETB receptor antagonist [21].

\section{Material and methods}

\section{In vitro pharmacology}

Pulmonary tissues were removed from 15 patients with lung cancer. The protocol was approved by the Ethics Committee of University Hospital of Lund, Lund, Sweden. After extirpation, the fresh part of the lung (not damaged by the cancer) was immediately immersed in cold $\left(4^{\circ} \mathrm{C}\right)$ buffer solution, aerated with carbogen gas with $5 \%$ $\mathrm{CO}_{2}$ in $\mathrm{O}_{2}$, resulting in a $\mathrm{pH}$ of 7.4. Small bronchi, from distal parts of the bronchial tree were dissected and cut into ring segments (1-1.5 mm long, with a diameter in the resting state of $0.5-1.0 \mathrm{~mm})$. Each segment was mounted on two L-shaped metal prongs $(0.2 \mathrm{~mm}$ in diameter), one of which was connected to a force displacement transducer (FT03C) attached to a MacLab unit for continuous recording of the isometric tension.

The mounted specimens were immersed in temperature-controlled $\left(37^{\circ} \mathrm{C}\right)$ tissue baths containing a buffer solution (see below). The solution was continuously aerated with carbogen gas resulting in a physiological $\mathrm{pH}$. Length-tension measurement was performed, comparing activated segments (exposed to $1 \mathrm{mM}$ acetylcholine) with similar segments exposed to $\mathrm{Ca}^{2+}$-free buffer solution for $24 \mathrm{~h}$, by step-wise increased of the distance between the metal prongs [22]. Thus, a tension of 1-2 $\mathrm{mN}$ was applied to the segments and they were allowed to stabilize at this level for $90 \mathrm{~min}$. The contractile capacity of each segment was examined by repetitive exposure to $1 \mathrm{mM}$ acetylcholine, which was used as a reference. Only segments with strong and reproducible contractions were used, i.e. less than $10 \%$ difference between two acetylcholine-induced contractions. After 30 min rest, the effects of the agonists were examined by cumulative application. There were no differences in the responses to ETs when concentration-response curves were obtained by cumulative application compared to a single-dose procedure. The tachyphylaxis caused by ET1 was investigated by the use of homologous desensitization tests. The bronchi were first contracted with ET-1, ET-2 or ET-3. After repeated washes, during a $90 \mathrm{~min}$ period, the initially contracted segment had returned to its resting state (baseline). A single dose of the same peptide $(0.3 \mu \mathrm{M})$ was then reapplied to the segment [17]. In antagonist experiments the segments were preincubated with FR139317 $(10 \mu \mathrm{M})$ or PD $145065(1 \mu \mathrm{M})$ for 15-20 min before agonists were applied.

\section{Light microscopy}

The bronchial segments corresponding to the in vitro studies were immersed into a formalin solution $(6 \%)$.
After fixation and staining with haematoxylin-eosin the segments were cut into thin cross-sections for examination with a light microscope.

\section{Solution and drugs}

Buffer solution (mM): $\mathrm{NaCl}, 119 ; \mathrm{NaHCO}_{3}, 15 ; \mathrm{KCl}$, 4.6; $\mathrm{MgCl}_{2}, 1.2 ; \mathrm{NaH}_{2} \mathrm{PO}_{4}, 1.2 ; \mathrm{CaCl}_{2}, 1.5$; and glucose, 11.

Drugs: ET-1, ET-2, ET-3 (Auspep, Parkville, Australia); IRL 1620 Suc[Glu $^{9}$, Ala $\left.{ }^{11,15}\right]$ - endothelin-1(8-21) (Ciba Geigy, Takarazuka, Japan); FR139317 (R)2-[(R)-2-[(S)-2[[1-(hexahydro-lH- azepinyl)]carbonyl]-amino-4-methylpentanoyl]amino-3[3-(1-methyl-1H-indolyl)]-propionyl]-amino-3(2-pyridyl)propionic acid (Fujisawa Pharmaceuticals Co., Osaka, Japan); PD 145065, Ac-D-Bhg ${ }^{16}$-Leu-Asp-IIe-Ile$\operatorname{Trp}^{21}$ (Parke-Davies Pharmaceutical Research, Ann Arbour, MI, USA); acetylcholine and histamine (Sigma, St Louis, MO, USA). The drugs were dissolved and further diluted in buffer solution or saline. Concentration-dependent potassium-induced contraction was performed using the above-mentioned buffer solution, exchanging $\mathrm{NaCl}$ for $\mathrm{KCl}$ giving a step-wise increase in potassium concentration up to $123.6 \mathrm{mM}$.

\section{Analyses}

The responses were characterized by $\mathrm{pD} 2$ values (i.e. the negative logarithm of the agonist concentration eliciting half the maximum contraction) and $E \max$ values (i.e. maximum contractile response induced by an agonist, expressed as a percentage of acetylcholine induced contraction). Statistical differences were determined with Wilcoxon signed-rank test and Mann-Whitney U-test for paired and unpaired groups, respectively. Probability values less than 0.05 were considered significant.

\section{Results}

The human bronchus segment used in this study (0.5$1.0 \mathrm{~mm}$ in diameter) presented discontinuous plates of cartilage and a typical pseudostratified columnar epithelium with numerous interspersed goblet cells (fig. 1). A layer of smooth muscle cells encircled the segments (fig. 1). According to the length-tension measurements these bronchi were able to develop their maximal contractile capacity at the passive level of $1-2 \mathrm{mN} \cdot \mathrm{mm}^{-1}$ (not shown).

Acetylcholine induced a concentration-dependent contraction with a $\mathrm{pD} 2$ of $5.44 \pm 0.17$ (number of patients $(n)=2$, numbers of segments tested $(z)=8)$ and a maximal contraction of $1.92 \pm 0.18 \mathrm{mN}(\mathrm{n}=15, \mathrm{z}=50)$. This response was without any sign of tachyphylaxis (fig. 2). Histamine (pD2 6.03 $\pm 0.13 ; E \max 95.6 \pm 9.8 \% ; \mathrm{n}=2, \mathrm{z}=8$ ) and potassium (pD2 1.59 \pm 0.11 ; $E \max 53.1 \pm 10.2 \%, \mathrm{n}=2$, 


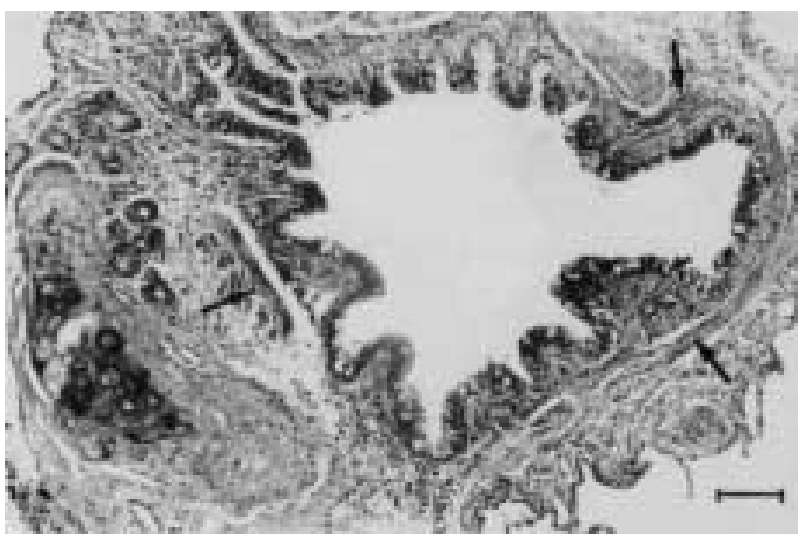

Fig. 1. - Histological section showing the cross-section of a small human bronchus. A discontinuous plate of cartilage, epithelial lining and goblet cells are visible. Arrows indicate the smooth muscle cell layer. (haematoxylin and eosin staining; internal scale bar=100 $\mu \mathrm{m}$ ).

$\mathrm{z}=8$ ) provoked concentration-dependent contractile responses with the same principal appearance as acetylcholine, i.e. fast developing and reproducible.

ET-1, ET-2 and ET-3 elicited similar strong, concentration-dependent contractions in human bronchus segments (table 1). The contraction was slowly developing and long-lasting (fig. 2). There were no significant differences in the tachyphylaxis for the three peptides; they all reached $57.6 \pm 8.3 \%$ of the initial contraction upon reallocation ( $\mathrm{n}=3, \mathrm{z}=7$; not shown). IRL 1620, a selective ETB receptor agonist, induced a similar contractile response to the three endothelins and the $E_{\max }$ and $\mathrm{pD} 2$ values were identical with the values for the ETs (table 1).

The ET-1-induced contraction was not affected by incubation with the selective ETA receptor antagonist FR139317 (10 $\mu \mathrm{M})$ (fig. 3a); pD2-values were 8.55 \pm 0.21 without and $8.72 \pm 0.20$ with antagonist (NS) and Emax values were $102.8 \pm 8.9$ and $100.6 \pm 15.7 \%$, respectively (NS). The combined ETA/ETB receptor antagonist PD $145065(1 \mu \mathrm{M})$ demonstrated a significant rightward shift of the IRL 1620-induced curve ( $\mathrm{pD} 26.79 \pm 0.36$; $\mathrm{p}<0.05)$ without affecting the $E_{\max }(110.1 \pm 36.0 \%$, NS) (fig. $3 b)$.

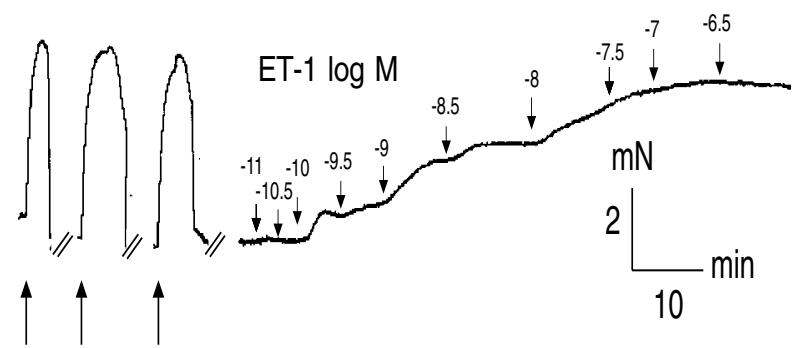

ACh

Fig. 2. - Typical example of concentration-dependent endothelin-1 (ET-1)-induced contraction of small human bronchus. At the beginning of the experiment the segment was repetitively (three times) exposed to $1 \mathrm{mM}$ acetylcholine (ACh) (used as a reference). Acetylcholine was removed by washing. Time between the contractions was not recorded. ET-1 concentrations are given as $\log \mathrm{M}$ at the curve.
Table 1. - The effects of ET-1, ET-2 and ET-3 and the ЕTв receptor selective agonist IRL 1620 on human small bronchi

\begin{tabular}{lrcr}
\hline & $\mathrm{n}$ & $\mathrm{pD} 2$ & \multicolumn{1}{c}{$E \max$} \\
\hline ET-1 & 8 & $8.58 \pm 0.24$ & $99.3 \pm 13.2$ \\
ET-2 & 5 & $8.73 \pm 0.19$ & $84.9 \pm 14.2$ \\
ET-3 & 5 & $8.05 \pm 0.38$ & $96.5 \pm 13.9$ \\
IRL 1620 & 12 & $7.97 \pm 0.24$ & $107.0 \pm 12.8$ \\
\hline
\end{tabular}

Emax: maximum contractile response in percentage acetylcholine-induced maximum contraction; ET: endothelin. pD2: potency expressed as negative log of agonist concentration eliciting 50\% of maximum contraction. The values are presented as mean \pm SEM, and the difference between groups are analysed by Mann Whitney U-test. No significant differences were seen between the agonists.

a)
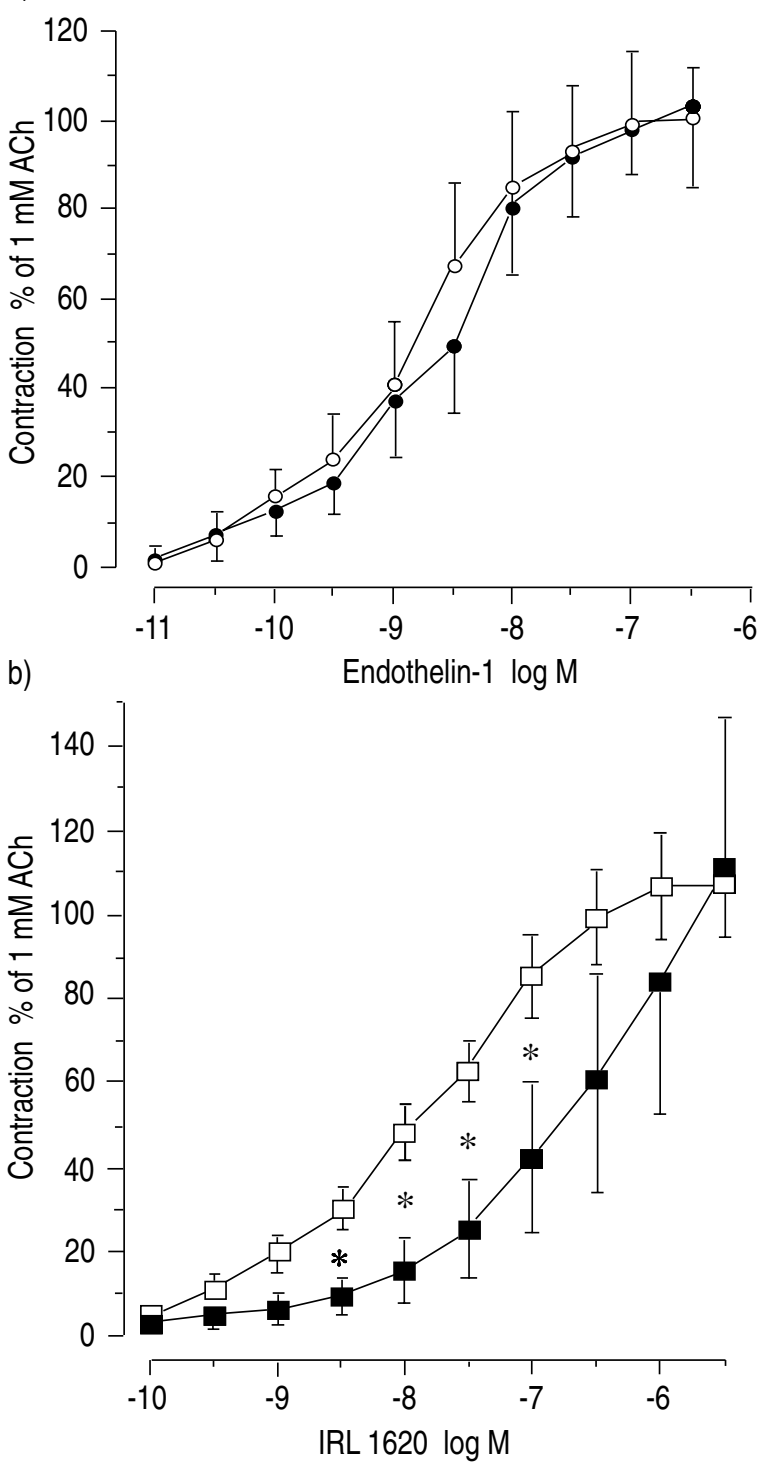

Fig. 3. - Endothelin (ET)-induced contractions in small human bronchi. a) ET-1 in absence $(\longrightarrow)$ and presence $(-\mathrm{O}-)$ of $10 \mathrm{nM}$ FR139317 $(\mathrm{n}=6)$. b) IRL 1620 in absence ( $\square-$ ) and presence (- - $)$ of 1 $\mathrm{nM}$ PD $145065(\mathrm{n}=6-12)$. Responses are expressed as percentage of the contraction induced by $1 \mathrm{mM}$ acetylcholine $(\mathrm{ACh})$. Each point represents the mean with the SEM shown by vertical bars. *: $\mathrm{p}<0.05$. 


\section{Discussion}

The present results indicate that the contractile capacity of human small bronchi located in the distal part of the tracheobronchial tree can be examined in vitro by the use of a modified tissue-bath technique. Reproducible values for acetylcholine, histamine and potassium were obtained. Furthermore, the three endothelins, ET-1, ET2 and ET-3, as well as the ETB receptor agonist IRL 1620 , induced concentration-dependent, strong contractions of isolated small segments.

A multitude of techniques have been utilized for studying mechanical activity in small isolated vascular smooth muscle preparations, but with a few exceptions most established in vitro methods for studying airways are confined to relatively large bronchi. However, the distal parts of the tracheobronchial tree are of considerable pathophysiological importance and several studies have shown that peripheral airways represent the most important part of the airways in the genesis of asthma and chronic obstructive diseases $[1,2]$. Furthermore, it is in bronchi smaller than $2 \mathrm{~mm}$ that morphological changes as a result of smoking have been demonstrated [23]. The present method allows studies of mechanical activity to be performed on small bronchi with lumen diameter down to $0.5 \mathrm{~mm}$. At this level, contraction of the thin smooth muscle cell layer that encircle the airway wall could result in a narrow obstruction [24]. In order to evaluate the optimal preload for detection of bronchial smooth muscle responses, length-tension measurements were performed according to Högestätt et al. [22]. These measurements revealed that the preload should be about $1-2 \mathrm{mN} \cdot \mathrm{mm}^{-1}$. It is reasonable to assume that this preload reflects a diameter at which the interaction between the contractile filaments is the optimum [25].

The effect of well-known contractile agonists were tested on the isolated bronchial segments. Acetylcholine and histamine showed a very similar contractile profile without any significant differences in $E \max$ or pD2. The results are consistent with the results of ADVENIER et al. [26] in bronchi with a diameter of 3-5 $\mathrm{mm}$. The buffer solution with a high potassium concentration showed contractions which were only $53 \%$ of the acetylcholineinduced contraction. When exposed to a single dose (1 $\mathrm{mM}$ ) of acetylcholine, these small bronchi showed a clear-cut contraction which was stable as well as reproducible, and therefore used as a reference [27].

Earlier investigations have shown that ETs are potent and strong contractors of human bronchi [16, 26, 27]. These studies were performed on large bronchi with a diameter of $3-15 \mathrm{~mm}$. In the present study, we examined smaller $(0.5-1 \mathrm{~mm})$ bronchi without semilunar cartilage. The ET-1-induced response at our distal level appeared to be notably stronger than the corresponding response previously reported for larger more central airways $[16,26,27]$.

The ET-induced contractions were slowly developing and long lasting. The contracted bronchus could easily be relaxed by washing, during which the segment quickly returned to the "resting" state and reapplication of an ETagonist resulted in a contraction corresponding to more than $50 \%$ of the initial tension level. These findings are consistent with previous findings in guinea-pig airways [17], and indicate the presence of an ETB receptor. In contrast, the ETA receptors is in most in vitro systems characterized by difficulties in "wash out", and by a complete tachyphylaxis upon reapplication [17]. The three ETs demonstrated equal potency which pharmacologically supports the presence of a contractile ETB receptor [28].

To further analyse the presence of another contractile subtype than the ETA receptor, recently developed pharmacological tools were used. IRL 1620, a selective ETB receptor agonist [19], showed a contractile response similar to that induced by the ETs. The ETA receptor antagonist FR139317 did not affect the ET-1-induced contraction, whereas the combined ET-receptor antagonist PD 145065 $(1 \mu \mathrm{M})$ shifted the IRL 1620-induced concentrationresponse curve to the right in a competitive manner, suggesting that the contraction of human small bronchi is mediated mainly by ETB receptors.

The present study shows that accurate in vitro studies can be performed on small human bronchi down to a diameter of $0.5 \mathrm{~mm}$. At this level ET-1, ET-2 and ET-3 induce strong and potent contractions, which can be mimicked by an ETB agonist (IRL 1620) and blocked by a combined ETA/ETB receptor antagonist (PD 145065), whereas a selective ETA receptor antagonist (FR139317) has no effect. Our pharmacological results, indicating the presence of a contractile ETB receptor on small human bronchi are in good agreement with recent autoradiographic findings, indicating dominance of ETB receptors in the human peripheral lung [29].

Acknowledgements: The authors wish to thank N. Kamei (Ciba-Geigy), J. Mori (Fujisawa Pharmaceutical Co.) and A. Doherty (Parke-Davies) for supplying us with IRL 1620, FR139317 and PD 145065, respectively.

\section{References}

1. Cosio M, Ghezzo H, Hogg JC, et al. The relations between structural changes in small airways and pulmonary function tests. N Engl J Med 1977; 298: 1277-1281.

2. Ebina M, Yaegashi H, Chiba R, Takahashi T, Motomiya M, Tanemura M. Hyperreactive site in the airway tree of asthmatic patients revealed by thickening of bronchial muscles. Am Rev Respir Dis 1990; 141: 13271332.

3. Leff AR. Endogenous regulation of bronchomotor tone. Am Rev Respir Dis 1988; 137: 1198-1216.

4. Cardell LO, Uddman R, Edvinsson L. Analysis of endothelin-1-induced contractions of guinea-pig trachea, pulmonary veins and different types of pulmonary arteries. Acta Physiol Scand 1990; 139: 103-111.

5. Yanagisawa M, Kurihara H, Kimura S, et al. A novel potent vasoconstrictor peptide produced by vascular endothelial cells. Nature 1988; 332: 411-415.

6. Inoue A, Yanagisawa M, Kimura S, et al. The human endothelin family: three structurally and pharmacologically distinct isopeptides predicted by three separate genes. Proc Natl Acad Sci USA 1989; 86: 2863-2867.

7. Masaki T, Yanagisawa M, Goto K. Physiology and pharmacology of endothelins. Med Res Rev 1992; 12: 391-421. 
8. Lagente V, Chabrier PE, Mencia-Huerta JM, Braquet P. Pharmacological modulation of the bronchopulmonary action of the vasoactive peptide, endothelin, administered by aerosol in guinea-pig. Biochem Biophys Res Commun 1989; 158: 625-632.

9. Pons F, Touvay C, Lagente V, Mencia-Huerta JM, Braquet $\mathrm{P}$. Comparison of the effects of intra-arterial and aerosol administration of endothelin-1 (ET-1) in the guinea-pig isolated lung. Br J Pharmacol 1991; 102: 791-796.

10. Black PN, Ghatei MA, Takahashi K, et al. Formation of endothelin by cultured airway epithelial cells. FEBS Lett 1989; 255: 129-132.

11. Vittori E, Marini M, Fasoli A, De Franchis R, Mattoli $\mathrm{S}$. Increased expression of endothelin in bronchial epithelial cells of asthmatic patients and effect of corticosteroids. Am Rev Respir Dis 1992; 146: 1320-1325.

12. Arai H, Hori S, Aramori I, Ohkubo H, Nakanishi S. Cloning and expression of a cDNA encoding an endothelin receptor. Nature 1990; 348: 730-732.

13. Sakurai T, Yanagisawa M, Takuwa Y, et al. Cloning of a cDNA encoding a nonisopeptide-selective subtype of the endothelin receptor. Nature 1990; 348: 732-735.

14. Takayanagi R, Ohnaka K, Takasaki C, Ohashi M, Nawata H. Multiple subtypes of endothelin receptors in human and porcine tissues: characterisation by ligand binding, affinity labelling, and regional distribution. J Pharmacol 1991; 17 (Suppl. 7): S127-S130.

15. Elshourbagy NA, Korman DR, Wu HL, et al. Molecular characterization and regulation of the human endothelin receptors. J Biol Chem 1993; 268: 3873-3879.

16. Hay DWP, Luttman MA, Hubbard WC, Undem BJ. Endothelin receptor subtypes in human and guinea-pig pulmonary tissues. Br J Pharmacol 1993; 110: 11751183.

17. Cardell LO, Uddman R, Edvinsson L. Evidence for multiple endothelin receptors in the guinea-pig pulmonary artery and trachea. Br J Pharmacol 1992; 105: 376380.

18. Cardell LO, Uddman R, Edvinsson L. A novel ETA- receptor antagonist, FR 139317, inhibits endothelininduced contractions of guinea-pig pulmonary arteries, but not trachea. Br J Pharmacol 1993; 108: 448-452.

19. Takai M, Umemura I, Yamasaki K, et al. A potent and specific agonist, Suc[Glu9 ${ }^{9}$ Ala $\left.{ }^{11,15}\right]$-endothelin-1(8-21), IRL 1620, for the ETB receptor. Biochem Biophys Res Commun 1992; 184: 953-959.

20. Sogabe K, Nirei H, Shoubo M, et al. Pharmacological profile of FR139317, a novel, potent endothelin ETA receptor antagonist. J Pharmacol Exp Ther 1993; 264: 1040-1046.

21. Cody WL, Doherty AM, He JX, et al. The rational design of a highly potent combined ETA and ETB receptor antagonist (PD 145065) and related analogues. Med Chem Res 1993; 3: 154-162.

22. Högestätt ED, Andersson KE, Edvinsson L. Mechanical properties of rat cerebral arteries as studied by a sensitive device for recording of mechanical activity in isolated small blood vessels. Acta Physiol Scand 1983; 117: 49-61.

23. Saetta M, Finkelstein R, Cosio MG. Morphological and cellular basis for airflow limitation in smokers. Eur Respir J 1994; 7: 1505-1515.

24. Moreno RH, Hogg JC, Paré PD. Mechanics of airway narrowing. Am Rev Respir Dis 1986; 133: 1171-1180.

25. Murphy RA. Contractile system function in mammalian smooth muscle. Blood Vessels 1979; 13: 1-23.

26. Advenier C, Sarria B, Naline E, Puybasset L, Lagente V. Contractile activity of three endothelins (ET-1, ET2 and ET-3) on the human isolated bronchus. $\mathrm{Br} J$ Pharmacol 1990; 100: 168-172.

27. McKay KO, Black JL, Armour CL. The mechanism of action of endothelin in human lung. $\mathrm{Br} J$ Pharmacol 1991; 102: 422-428.

28. Bax WA, Saxena PR. The current receptor classification: time for reconsideration? Trends Pharmacol Sci 1994; 15: 379-386.

29. Knott PG, D'Aprile AC, Henry PJ, Hay DWP, Goldie RG. Receptors for endothelin-1 in asthmatic human peripheral lung. Br J Pharmacol 1995; 114: 1-3. 